\title{
Rebeliões urbanas e a desestruturação das classes populares (França, 2005)
}

\author{
Stéphane Beaud e Michel Pialoux \\ Tradução de Vera Telles \\ Revisão técnica de Sergio Miceli
}

M uitos observadores franceses ficaram surpresos com as rebeliões urbanas que, em novembro de 2005, se seguiram à morte de dois jovens da periferia parisiense - ambos de 15 anos, filhos de imigrados malineses e tunisianos (lixeiros em Paris) - que, perseguidos pela polícia quando voltavam de um jogo de futebol, se refugiaram em uma central elétrica, onde morreram eletrocutados. Tendo publicado, em 2003, o livro Violences urbaines, violence sociale [V iolências urbanas, violência social], cujo ponto de partida foi uma "rebelião urbana" em M ontbéliard, esses acontecimentos não poderiam ser uma surpresa para nós. As últimas frases do livro evocavam a amplitude das discriminações sofridas pel os jovens franceses filhos de imigrados e se interrogavam sobre as conseqüências sociais do impossível acesso, para a maioria deles, a um emprego estável. E o livro terminava com estas palavras: "Q uantas bombas de efeito retardado!". N ão era necessário ser adivinho para antecipar o futuro, pois a recorrência de rebeliões urbanas na França, nos últimos quinze anos, está inscrita em uma "ordem das coisas" que remete a fenômenos estruturais: 0 desemprego dos jovens com baixa escolaridade, a precarização sem saída, o agravamento da segregação urbana, o fracasso escolar, a pauperização ea desestruturação das famílias populares nos conjuntos habitacionais $\mathrm{H} \mathrm{LM}^{1}$, a discriminação no recrutamento, o racismo ordinário etc. São fenômenos que produzem, no correr do tempo, uma violência social multiforme nem sempre visível, mas que, condensada e coagulada, pode

1. H LM : H abitação de Locação M oderada. Conjuntos habitacionaisconstruídospelo governo francês nos marcosdeum amplo programa social de moradia destinado às classespopulares. D iferente da situação brasileira, esse foi o padrão demoradia paraagrandemaioriadas classes populares, em particular dos enormes contingentes de trabaIhadores que se instalaram nasperiferias urbanasa partir do pós-guerra. 0 acesso à propriedade da moradia só começa a segeneralizar em meados dos anos de 1980, maisintensamenteno início da década de 
1990, quando entra em vigor uma política deliberada do governo francêsno sentido defacilitar o crédito e a aquisição da moradia própria, em grandepartepeque nos prédios de apartamento construídos em loteamentos afastados dos grandes conjuntos habitacionais. Esse foi um fator considerável paraafuga dascamadas sociais mais estáveis e com maior renda dos grandes conjuntos. No correr dessesanos, esses conjuntos terminaram por concentrar justamente os trabalhadores mais precarizados, sobretudo asfamílias imigradasea geração deseus filhosjánascidosem território francês. A respeito, ver 0 artigo deO liver M asclet incluído neste número da revistaTempo Social (N.T.).

2. Como prova de sua interpretação das rebe liões - bandos de "pilantras" que semeiam a desordem nos bairros populares-, 0 ministro do Interior tirou do cha péu dados estatísticos que estabeleciam que $80 \%$ dos jovens apresentados à Justiça seriam "bem conhecidos dos serviços depolícia". Essa estatística, brandi- eclodir de uma hora para outra. Basta um detonador. Para conferir sentido a uma rebelião urbana, que sempre produz um efeito de surpresa, por vezes estupefação, é preciso, antes de tudo, colocar em evidência essa violência invisível, pouco espetacular - se bem que não é pouco o quanto dela se fala nas mídias. A penas essa violência social podeexplicar a espécie de raiva autodestrutiva que caracteriza tais rebeliões.

\section{A falsa oposição entre "ralé" e "verdadeiros jovens"}

Essa perspectiva sociológica supõe necessariamente passar pela históriae pela compreensão da gênese das disposições. Ao contrário disso, o discurso sobre as violências urbanas proferido pelos representantes das instituições (polícia, justiça, escola), ou pelos homens políticos, volta-se, quase sempre, para a busca ea designação dos "cul pados" - os "arruacei ros" (casseurs) ou os "delinqüentes", como diz Sarkozy -, esses que teriam participado ativamente do movimento e que seria preciso neutralizar o quanto antes. Passam a impressão de que, para restabelecer a calma e pacificar os bairros populares, bastaria focalizar os "microgrupos" que se constituem em torno de seus líderes (os caïds) e isolá-los de uma vez por todas. Esse discurso policialesco tem a particularidade de ocultar a gênese das atitudes e dos grupos rotulados como desviantes. É um discurso que se alimenta de uma etiologia sumária do fenômeno da violência e que se apóia numa dicotomia apaziguadora: de um lado, um núcleo de "violentos", "irredutíveis" e "selvagens", dos quais não se ousa dizer que são irrecuperáveis e não reeducáveis (mas é, no entanto, o que pensam muitos dos responsáveis políticos), e, de outro, os jovens "não violentos" que se deixam levar e que seria preciso proteger contra a contaminação dos demais.

Podemos reconhecer aí as grandes linhas do discurso do ministro do Interior, que, ao endurecer a linguagem, parece reativar o vocabulário das classes dominantes do século XIX confrontadas com as rebeliões populares. Assim, desde os primeiros dias, os revoltosos foram rebatizados por Sarkozy, em uma lógica de provocação calculada, com o nomede "ralé". A expressão teve um papel decisivo na difusão das "rebeliões" de Clichy-sous-Bois para a região parisiense e para toda a França. Essa "semântica guerreira", para retomar as palavras de outro ministro (Azouz B egag), pretendefazer acreditar que havia, de um lado, os "delinqüentes" e "arruaceiros", e, de outro, os "bons jovens" (os "verdadeiros jovens", como disse certa vez o ministro na televisão). Como se fosse suficiente separar o joio do trigo². Ainda resta 
fazer a sociologia dos jovens denunciados à Justiça (perto de 3 mil). Porém, os dados das audiências mostram que, ao contrário das declarações do ministro do Interior, trata-se de jovens "comuns", que pertencem aos meios populares: al guns já terminaram seus estudos, outros fazem bicos (empre gos temporários, vendedores ou ajudantes de cozinha) e outros ainda estão estudando. Sem fichajudiciária, eles mergulharam no movimento, atraídos pela efervescência do momento, levados pelo mesmo sentimento de revolta, em meio a uma experiência compartilhada das mesmas condições sociais de existência, conscientes de pertencer a uma mesma geração sacrificada. $Q$ uanto aos menores, o juiz J ean-Pierre Rosenczveig constatou que, no tribunal de Bobigny, dos 95 menores apresentados apenas dezessete eram conhecidos daJ ustiça: "Alguns eram conhecidos não por terem cometido al gum ato de delinqüência, mas porque eram objeto de alguma medida de assistência educativa para crianças em situação de risco" (Le Figaro, 19/11/2005).

\section{A comunidade de experiência dos jovens dos conjuntos habitacionais}

Esses dados contradizem a cômoda tese que imputa as rebeliões urbanas à ação perniciosa exclusiva da "ralé". É preciso, primeiro, compreender que a juventude das periferias francesas constitui um universo social diferenciado. E, depois, analisar as razões que podem levar jovens "comuns" a se juntar ao movimento lançado pela fração potencialmente mais violenta.

Contrariamenteàs representações correntes, essa juventudenão sereduz apenas à sua fração mais visível no espaço público, qual seja o núcleo duro de jovens desempregados (em certas regiões populares, chegam a $40 \%$ entre os jovens de 15 a 25 anos). Esse grupo social inclui, de um lado, os jovens que trabal ham, principalmente operários ou empregados, quase sempreem empregostemporários ou com contratos de curta duração, e, de outro, um contingente de jovens escolarizados, entre os quais estudantes orientados para carreiras (ensino técnico ou profissional) queeles percebem como de rel egação escolar, alunos em liceus deensino geral, bem como estudantes defaculdade ou ainda dos cursos técnicos superiores (muito raramente nos cursos preparatórios paraas $G$ randes Escolas do ensino superior). Além desses, uma minoria de jovens com profissões intermediárias (professores do segundo grau, educadores, animadores etc.) que continuam a viver com seus pais ou que preferiram continuar morando nosmesmos conjuntos habitacionais.

Existem clivagens fundas entre esses grupos, sobretudo entre as frações contrastantes: de um lado, os estudantes bem situados em sua busca de da como troféu erepetida à exaustão pelas mídias audiovisuais, é inaceitável. Asprimeiras audiências dos"revoltosos" no tribunal de Bobigny mostraram quea maioria deles não tem antecedentesjudiciários e não podem ser rotulados como "delinqüentes". A pena mais pesada atéagora pronunciada (quatro anos de prisão paraum incendiário de uma grande loja de tapetes) diz respeito a um jovem de 20 anos, trabalhador temporário, titular de um diploma técnico depintura, filho deum operário francês morador da periferia de Arras. 
diplomas e, de outro, os jovens desempregados ou os estudantes empurrados para as escolas profissionais que eles próprios não escolheram, e que se percebem sem futuro. São principalmente estes que, com mais tempo disponível, formam bandos que se reúnem na frente dos prédios para discutir, passar o tempo, fumar seus "baseados", "delirar" um tanto, tudo isso em meio a um sentimento intenso de autodepreciação. Esses bandos não são mundos fechados e estanques: em certos momentos e conforme as circunstâncias, a eles se juntam jovens mais escolarizados que aí encontram o prazer do convívio masculino. Para além das diferenças internas de status, existe uma grande porosidade entre as diversas frações dessa juventude. E isso é fundamental de ser bem compreendido. É essa porosidade que permite, por exemplo, queum jovem situado nos postos mais el evados e mais valorizados do sistema de ensino, mas que sofreu uma forte discriminação em sua busca por um estágio, possa se juntar pontualmente ao combate de seus companheiros de infortúnio, muito freqüentemente pouco escolarizados. Em certos momentos, o que os aproxima é mais forte do que aquilo que os separa. Esses rapazes cresceram juntos nos mesmos locais de moradia e partilham uma comunidade de experiências que cria laços muitos fortes entre eles ("para toda a vida, até a morte"). Comunidade de experiências vivida freqüentemente na forma de gangues, marcada pela mesma privação material, pelas mesmas humilhações derivadas de uma pobreza endêmica, e associada à cor da pele (controles pessoais reiterados, polícia cada vez mais agressiva e brutal com os negros e os árabes, que são a grande maioria dos moradores dos conjuntos habitacionais na região parisiense). São estigmas que não se apagam. $\mathrm{N}$ ão se pode, por exemplo, compreender a recente e enérgica manifestação de Lilian Thuram, "miliardário do futebol", contra as declarações de Sarkozy ("É preciso saber por que as pessoas ficam assim! $\mathrm{N}$ ão existe agressividade gratuita, não acredito nisso. É preciso ir mais longe") sem levar em conta que a sua consciência política foi forjada no convívio com essajuventude, em contato com as discriminações e com o racismo que eram o pão cotidiano de sua vida então. São estigmas que não se apagam, qualquer que seja o nível de renda conquistado, ao contrário do que pensa o ministro que pretendeu desqualificar as declarações do jogador de futebol com ironias a respeito de seu elevado padrão de vida.

A verdadei ra questão sociológica suscitada por essas revoltas éa seguinte: como explicar a participação dosjovens "comuns" nesses acontecimentos?É como se os comportamentos de autodestruição, atéentão reservados à fração mais humilhada dessa juventude, tivessem progressivamente se difundido 
entreaquelesque, atépouco tempo atrás, esperavam conseguir searranjar na vida por meio da escola, ou então pelo empenho no trabalho. Talvez esteja nisso a verdadeira novidade desse movimento: a desesperança social, antes reservada aos membros mais dominados da juventude - e que se expressa notadamenteno uso dedrogas, nos comportamentos derisco (roubos, dirigir como "loucos" ao volantedoscarros) - , pareceter atingido osjovensoperários eosmais escolarizados (bacheliers) ${ }^{3}$, atéagora menos afetados por esse infortúnio. Entreeles, muitosperderam a paciência ea esperança, à força detanto bater contra o muro da discriminação e do racismo, acumulando, assim, no correr do tempo, um enormeressentimento. D efato, o futuro objetivo desses jovens, detodoseles, ficou dramaticamentemais sombrio nosúltimosanos. N inguém ignora que a situação dos empregos degradou-se a partir de 2000. Porém, o quetalvez não se conheça tão bem éo fato de que essa degradação atingiu em cheio osjovens desses conjuntos. Entreos diplomados do secundário, quepenam para encontrar um lugar no mercado detrabal ho, a discriminação na hora do recrutamento pesa duramente, e acaba rebatendo com violência naqueles diretamenteafetados, ainda maisquando os refúgios (contratossubsidiados, empregos para jovens) antes oferecidos a esses estudantes foram aos poucos se inviabilizando. É preciso insistir sobre a extinção dos "empregos para jovens" ${ }^{4}$, pois de al guma forma el es permitiam a esses estudantes se reerguer e recuperar a confiança em si depois do fracasso em seus estudossuperiores, Ihes oferecendo uma situação, uma renda, possibilidades dese estabelecer esonhar com um futuro melhor. Entreosjovensoperários, a precariedade aumentou grandemente nos empregos não-qualificados, para chegar a essa obra-prima da desregulamentação do mercado de trabal ho que são os chamados contratos "novos-empregos". N a região parisiense, onde as possibilidades de emprego são maiores (fábricas, construção, hotelaria erestaurantes, terciário não-qualificado), uma parte consi derável desses jovens trabalha em empregos manuais: em fábricas, no aeroporto de Roissy, no terciário não-qualificado (triagem postal, telemarketing etc.). Porém, depois do 11 de setembro, Roissy, que era um grande empregador de jovensmoradoresdosconjuntos habitacionais, pareceter feito a "limpeza”, por conta dos temores de ameaça terrorista. C itröen Aulnay dispensou recentemente seiscentos trabal hadorestemporários, eR oissy anunciou 550 dispensas detemporários, em 2005. Aspequenasmel horias do mercado detrabalho não duraram muito, o mau tempo está de volta. A degradação também afetou as condições de trabal ho. Estresse, fadiga, "ambiente apodrecido", essas são as palavrasquevoltam freqüentementequando elesfalam dosnovos serviçosou
3. Bachelier, o estudante titular de um baccalauréat, ou bac: trata-se de um diploma conferido aosque passam por um exameaplicado após a conclusão do secundá rio eque os credencia a seguir o ensino universitário. Correspondeao primeiro estágio universitário (N . T.).

4. U ma entre as várias formas de empregos subsidiados (os chamadosemploisaidés, literalmente, empregos-ajudados) estimulados pelo governo francês nos marcos de políticas de emprego praticadasdes de os anosfinais da dé cada de1980 emaisamplamente nos anos de 1990 (N.T.). 
5. D esignação dos descendentesdeimigrantes magrebinos (do $\mathrm{M} \mathrm{a-}$ greb, norte da África: M arrocos, ArgéliaeTunísia, ex-colôniasfrancesas) nascidosna França (N.T.).

6. Diminutivo do nome próprio Paul. D esignativo utilizado paracrianças ou jovens franceses brancos. Q uando utilizado para um jovem descendente deárabes, ganha um significado pejorativo, querendo convertêlo em algo que elenão é(N . T.). dasfábricas em fluxo-contínuo. Entre os jovens quetrabalham, muitos percebem sua situação como um fracasso: não conseguem escapar dos empregos precários, com contratos de curta duração ou como temporários. Ainda que não empreguem essa palavra, elessão "operários" sem qualificação com grandeschances deassim permanecer. $N$ ão terão meios demelhorar sua condição social e serão obrigados a reproduzir o modelo paterno do qual quiseram quasesempreselivrar. Como disseum rapaz em uma reportagem do "Envoyé Spécial", "nós somos manuais... como nossos pais [sorriso triste], com uma coisinhaa mais, eétudo". Paraeles, o insuportável éesse sentimento de estar destinado a ficar no mesmo lugar, uma recusa visceral deaceitar essa condição operária doravanteassociadaà iniqüidade.

É preciso ainda lembrar que as experiências de trabalho desses jovens podem ser muito difíceis de serem vividas. A condição dos filhos deimigrados tornou-se infinitamente mais complicada com o aumento do terrorismo praticado pelo islamismo radical. O s controles multiplicaram-se no espaço público, mas também nasfábricas. U m beur ${ }^{5}$ éum suspeito por natureza: seja como potencial aliado das ações terroristas, seja como "muçulmano" contrário à lei do véu etc. Assim, Karim, 22 anos, conta que seus colegas de trabal ho nunca são chamados pel o nome, mas por um apelido que provoca o riso a cada vez que épronunciado: "Al Q uaeda". U m estudante de $N$ antes conta que um amigo, temporário como ele em Saint-N azaire, de nome Farid, foi brindado pelo seu chefe com o apelido "Petit Popaul" 6 - eéassim que foi chamado durante os seis meses de trabal ho temporário. Seria possível multiplicar esses exemplos que mostram o custo elevado a ser pago por esses jovens por conta de sua integração profissional. Essas experiências de trabalho, esses casos circulam o tempo todo nos conjuntos habitacionais. U ma vez transposta, timidamente, a porta da empresa, além da discriminação há também a hostilidade surda, por vezes o racismo aberto, tudo isso tendo deser enfrentado por eles. Essesjovens têm a impressão denão serem bem-vindos no mundo do trabal ho. Talvez essa seja uma grande diferença em relação aos operários veteranos, que entraram em um mundo operário talvez também reticente e inclusive hostil em relação aos "jovens árabes", masqueera mais estruturado, maismarcado pela presençasindical. 0 mundo operário apósa "classe operária" émais anômico, minado pela precariedade, mas também pelas invejas e pela concorrência interna exacerbadas pelas novas formas de organização do trabal ho. Conseqüência: para esses jovens, conquistar um lugar no mercado de trabalho exige sempre mais efforço, mais abnegação, mais comedimento... Porém, eles pertencem a uma gera- 
ção social quefoi marcada pela vida nos conjuntos habitacionais, a qual não quer desempenhar o papel de "rebaixados" e tampouco reproduzir a lógica das humilhações vividas pelos pais.

As experiências vividas pelos rapazes - no trabalho, no espaço público, na relação com a polícia (ponto essencial que não será aqui tratado) - circulam o tempo todo nas conversas entre os grupos de jovens e também no interior das famílias. N ão é de espantar, portanto, que as meninas, apesar de sofrerem formas cotidianas, por vezes violentas, de dominação masculina exercida pelos rapazes (uma delas fal ou com graça a um jornalista de Politis: "Nós, no conjunto, vivemos em permanente toque de recolher"), não deixaram de exprimir uma solidariedade muda para com os garotos nas revoltas de 2005: elas vivem, no cotidiano, a degradação das condições materiais de existência nesses conjuntos e também sabem, por experiência própria, que o racismo é sexuado eatinge mais duramente os meninos. Podem condenar a violência gratuita, notadamente contra as escolas, mas não deixam de compreender a desesperança de seus irmãos. Tampouco é de espantar que os pais imigrados, pais e mães igualmente, tenham manifestado uma enorme ambivalência diante da revolta de seus filhos. Pudemos observar quea forte condenação moral da violência (pois "isso não éuma solução") é muitas vezes arrefecida, quase que no mesmo movimento, pela tímida evocação das "circunstâncias atenuantes", a saber, o desemprego, o racismo, a discriminação. $N$ ão éde espantar, enfim, queos caçulas dasfamílias imigradas, que vêem diariamente a situação dos irmãos mais velhos - de 25 a 30 anos, que ainda moram na casa dos pais, passando de um contrato precário a outro, sem esperança de um emprego estável -, tendam a radicalizar-se precocemente. São garotos que descrevem os conjuntos como um lugar cada vez mais "difícil de viver". Trata-se de uma geração social que cresceu em meio à crise e à precariedade, e que amiúde testemunhou o "desastre" instaurado em suas famílias: desqualificação social dos pais, divórcio ou separação, desemprego recorrente dos irmãos mais velhos e impossibilidade de "fazer sua própria vida", prisão ou internamento psiquiátrico, suicídio etc.

Para compreender as rebeliões urbanas de novembro de 2005, é preciso medir e sentir o quanto é decisiva a experiência vivida, cada vez mais cedo, da desesperança social nos meios populares. É preciso, portanto, não restringir a análise apenas ao que acontece nos locais de moradia, em particular nos conjuntos habitacionais, e inscrever tais acontecimentos no quadro mais amplo da desestruturação das classes populares francesas. Para colocar em outros termos: é preciso tentar compreender o que vem ser a condição 
7. M ichel Pialoux deu início à pesquisa em Sochaux em 1983. Sté phane Beaud chegou ao campo pela primeiravez em 1988.

8. N osso livro inscreve se no quadro de uma filiação teórica, a da sociologiadePierreBourdieu edo centro depesquisa queeledirigiu por trinta anos. $\mathrm{Na}$ França, a análise das classes sociais progrediu graças ao aporte de uma abordagem relacional e "construtivista", amplamente iniciada pelos trabalhos de P. Bourdieu e L. Boltanski, edepoisreapropriada por historiadores (como G. N oiriel) epolicólogos (como B. Pudal). Para esses autores, osgrupossociaisnão são substancializados como nas análises marxistas; são, ao contrário, pensados e analisados como umarealidadesociohistórica, produzida no tempo, notadamentepor um trabalho simbólico epolítico de representação (por isso, podese dizer que esses gruposforam "construídos"). N essequadro teórico, alutadeclassesnão ocorreapenas no plano das relações de produção (ou das fábricas), mastambém mediante operária "após a classe operária". Essa é, a nosso ver, a questão central a ser bem entendida. E essa éjustamente uma questão que se impôs ao longo de uma pesquisa que desenvolvemos por mais de quinze anos na região de Sochaux-M ontbéliard, onde está instalada a sede da automobilística Peugeot ${ }^{7}$, eque resultou em nosso livro Retour sur la condition ouvrière (Fayard, 1999).

\section{Os operários apósa "classe operária"}

Em novembro de 1999, quando preparávamos a publicação do livro Retour sur la condition ouvrière, chegamosa propor, em um primeiro momento, o título "O perários após a classeoperária”. Essa formulação correspondia ao propósito teórico subjacenteao livro ${ }^{8}$ e sugeria uma questão política para nósessencial: em quesetransformaram osoperários sem o suportematerial e simbólico que a "classe operária", por muito tempo, Ihes ofereceu, isto é, a "classe" organizada sindical mente (sobretudo por meio daCGT - Confederação G eral do Trabal ho) epoliticamente(sobretudo o PCF - Partido C omunistaFrancês- enasorganizações políticas guiadas pelo socialismo)?0 poderoso capital coletivo, material e simbólico, acumulado durante décadas de lutas sociais por meio do movimento operário (em sentido amplo), permitiu ao grupo operário se estruturar em "classe mobilizada", e esta, por sua vez, facilitou enormementeo trabalho cotidiano derepresentação social epolítica do grupo pelossindicatose partidos, bem como por várias associações locais.

Ao cabo de quinze anos de pesquisas e publicações diversas, quando 0 livro foi publicado, em 1999, nos parecia evidente que uma página da história havia sido virada. Estávamos diante de outra configuração histórica: a "classe operária" (para retomar provisoriamentea expressão) estava na defensiva - "estamos sempre recuando", no linguajar dos militantes -, enfraquecida, amplamente desarmada emuito desmoral izada. Com o recuo do tempo, poder-seia mesmo dizer que esse período (iniciado com a emergência, na cena política e sindical, da "geração singular" da época da Frente Popular), de 1936 a 1980, constitui apenas um parêntese em uma história de longa duração do movimento operário francês: um período, a mais de um título excepcional, em que a "classe operária", com a sustentação do Estado Social imposto pelas forças da Resistência, cresceu continuamente em número e se reforçou politicamente, arrancando das classes dominantes uma série de di reitos sociais, as ditas "vantagens sociais" que os últimos anos não cessam de colocar em questão. 
N esse livro, tratávamos de compreender um processo central na história da sociedadefrancesa: a desestruturação da antiga "classe operária", tal como ela se constituiu ao longo do tempo. Para tanto, era preciso dar conta não apenas de seu (relativo) enfraquecimento numérico, mas sobretudo de seu enfraquecimento político, e que se traduz por aquilo que poderíamos chamar de perda da autonomia simbólica tão característica dos últimos vinte anos. Enfim, tratava-se de compreender como foi possível, em duas décadas, passar tendencialmente de uma situação na qual a "classe operária" era obje to de todas as atenções sociais e políticas - notadamente da parte dos intelectuais (cf. a legendária foto de Sartre discursando sobre um caixote em Billancourt) - para outra em que, ao final dos anos de 1990, não suscitava o interesse de mais ninguém, uma situação na qual, à força do reiterado adeus ao proletariado por parte dos intelectuais que dela haviam feito uma causa sagrada em seus anos de juventude, passa-se a acreditar até mesmo que ela havia desaparecido das estatísticas 9 . Enfim, uma classeque não fala mais ou, pior, que se tornou objeto de um discurso de comiseração. Essa questão de denominação, das palavras sociais, nos coloca ante um problema central na construção social do grupo operário ${ }^{10}$. Por exemplo, as palavras empregadas para designar os operários contribuem, a seu modo, para construir a realidade. Falar, como antes, de OS (operário especializado) e de "operários nãoqualificados", ou, agora, de "operadores" e de "BN Q " (baixo nível de qualificação), não éexatamentea mesma coisa. Asmudanças nas palavras envolvem toda uma relação com o mundo. Antes, nos anos de 1960 e 1970, a palavra "operário" era fortee evocadora. D epois, para dizêlo um tanto esquematica mente, quanto mais a classe operária se enfraquece simbolicamente, tanto menos ela consegue se nomear a si mesma, e tanto mais o termo "operário" fica desvalorizado no mercado lingüístico das profissões, justo o contrário do termo forte e evocador daqueles anos. $N$ a medida em que a classe operária deixa de atemorizar e de falar por intermédio de seus próprios portavozes, tanto mais os diferentes formadores de opinião conseguem, para de signá-la, impor nomes cuja função é eufemizar e "encantar" a realidade da condição operária, ao mesmo tempo em que essa realidade é vivida de maneira cada vez mais dolorosa pelos próprios operários.

Assim, é importante estabelecer a relação entre esse processo de desestruturação da classe operária e as mudanças ocorridas não apenas no sistema de relações econômicas (eis o aporte da tradição marxista), mastambém em outras efferas da atividade social (escola, moradia, família). D essa forma, no Retour..., em um primeiro momento, na parte consagrada à fábrica de lutasde classificação social em torno da representação dosgrupossociais e, portanto, das suas formas de visibilidadeno espaço público. Trata-se, portanto, de articular, na análise, a questão das relações de dominação queseestruturam noslocais detrabalho eas lutas simbólicas, em particular as que se processam no campo intel ectual.

9. Poucas passagens do livro chamaram tanto a atenção como aquelas nasquais comentamos, logo nas primeiras páginas, queosestudantes de sociologia estimavam o número deoperáriosna França em alguns miIhares (entre 300 e 600 mil). Váriosjornalistas nos disseram terem feito, de improviso e em uma espécie de jogo, a mesma pergunta a seus colegas de trabalho. As respostasforam sempre no mesmo patamar, os números nunca ultrapassando 1 milhão. N ão deixa de suscitar uma imensa interrogação o fato da subestimação no número real deoperários atingir essa amplitude.

10. O shistoriadores ( $\mathrm{E}$. P. Thompson, W. H. Sewel, G. Noiriel) e, depois, os policólogos 
(M. O fferlé, B.Pudal) semprelevantaram, em seustrabalhos, essaquestão etrouxeram respostas que fizeram avançar grandemente a sociologia histórica da classe operária. Entreoutras, a importância da linguagem para compreender a constituição de um grupo social.

11. U m pouco como C. D ejours fez com sua equipedepsicodinâmica do trabalho.

12. São trabalhos grandemente construídos contra essa sociologia percebida como "determinista" e "derrotista". Por medo de tratar de questões como a dominação ou as relações de classenaescola, essanova sociologiaterminou por setranformar em uma sociologia da escola (ou da instituição escolar) ou uma sociologia da avaliação: uma desuasprincipaiscaracterísticaséser muito pouco atenta ao que sepassa fora do sistema escolar.
Sochaux, buscamos colocar em evidência a maneira como as lógicas de dominação e de exploração se perpetuam ou se renovam no trabalho, podendo ser, hoje, ainda piores do que antes ${ }^{11}$. C ertamente, uma questão que jamais poderia ser apreendida sob o ponto de vista dos gestores e dos managers, e que passa amplamente despercebida pelos autores que fizeram suas pesquisas sob a ótica da racionalidade gestionária imperante nas empresas. Em um segundo momento, adotamos uma postura de pesquisa que, na linhagem das investigações teóricas e empíricas de Bourdieu, indo além desse tipo de abordagem "marxista", busca levar em conta outras mudanças que nos parecem decisivas, pertinentes às transformações das relações intergeracionais e à construção da estima de si em um espaço social que, ele próprio, se transforma o tempo todo.

D aí a ênfase, em nossa pesquisa, no que se passa na escola - não nas fileiras mais nobres do ensino, mas em seus segmentos (tornados) desvalorizados, como é o caso do ensino profissional. H oje, é possível reconhecer: a política voluntarista de democratização escolar - com a legião de falsas aparências - terminou por supervalorizar o ensino geral, que se tornou, na boca dos alunos, a "via normal". N o entanto, essa é uma via cheia de emboscadas earmadilhas para os jovens do meio popular, que não têm os "códigos" para o sucesso escolar. As dificuldades da democratização escolar não tardaram a aparecer aos olhos das famílias envolvidas na nova competição escolar. M as apareceram depois, quer dizer, quando seus fiIhos, aos 22 ou 24 anos, perceberam que os resultados nem sempre correspondiam às promessas. Essa política teve também um pesado custo para o mundo operário, pois, sem garantir o sucesso no ensino geral, também acabou privando esses jovens de um apoio que, apesar de tudo, era bastante sólido: o credenciamento escolar e o reforço da confiança em si operado nas escolas profissionais. Porém, no sistema atual, o que nos parece amplamente subestimado, talvez "esquecido", pela sociologia da educação dos anos de 1980 e 1990, pós-Bourdieu-Passeron², é a emergência de uma forma renovada (e desconhecida) de dominação, que se traduz em formas de humilhação escolar e, para os alunos relegados às fileiras escolares menos cotadas, um sentimento muito vivo de rejeição, de ter sido descartado, colocado de lado (quase que "para toda a vida"). Inútil procurar mais longe a origem da "violência escolar" de hoje. Fundamentalmente, ela se enraíza nesse processo de descarte precoce e de banimento social dos que se deram mal no sistema escolar (a saber, majoritariamente, os filhos das famílias mais proletarizadas). 
Assim, para compreender as transformações do mundo operário, é preciso ter sempre em mente o quanto isso tem a ver com a relação das famílias com a escola. Sem fazer disso uma explicação primordial, é certo que, no entrecruzamento dessas mudanças, desapareceu grande parte do que antes fazia o "sentido de classe" dos operários. O s militantes operários do início do século XX eram melhores sociólogos do que se imagina, ao resistir à difusão da cultura escolar em meio operário, ou então "sem hesitar em se mostrar reticentes ou mesmo críticos perante a 'escola secundária'. 0 regime de estudos prolongados produziu certo tipo de aculturação escolar no qual o que se perde, entre os "filhos da democratização" (cf. Beaud, 2002), é certa forma de cultura operária, que era em parte feita de atitudes de oposição e disposições rebeldes (para os filhos da fração politizada da classe operária). A passagem por um regime de estudos prolongados contribuiu para desqualificar a experiência operária e pode produzir efeitos de vergonha social entre os alunos "médios", que são "desaculturados" (perda da cultura operária de origem), mas não verdadeiramente aculturados em termos escolares, flutuando assim entre diversas referências de pertencimento.

As transformações na escola, ocorridas na França a partir do início dos anos de 1980 - desvalorização do ensino profissional e promoção de um modelo de estudos prolongados no ensino geral, lógica de alternância, aumento do aprendizado, alongamento da escolaridade etc. -, tiveram, no correr do tempo, múltiplas conseqüências, amplamente despercebidas, em especial no mundo operário. Portanto, a questão das gerações (e a ruptura entre as gerações) é central, e é isso o que permite e nos permitiu articular estreitamentea questão das transformações do trabal ho operário, da escolae a crise da herança operária. D e fato, o processo estrutural de desval orização operária na fábrica foi, ao longo desses quinze anos, redobrado por outros processos de "desoperarização" fora da fábrica, sobretudo por meio de mudanças nas aspirações escolares e profissionais das famílias operárias, da desval orização das práticas "tradicionais" que afeta tanto a maneira de educar os filhos, como também tudo o que poderíamos chamar de "senso de classe". Em nossa pesquisa, surgiu uma questão que é, hoje, central para as famílias operárias: a dificuldade ou a impossi bilidade de transmitir uma herança. À diferença do que se passa entre outros tipos de família, ainda mais entre as famílias burguesas, os pais do meio operário parecem não mais saber o quê transmitir a seus filhos, seja no plano individual, seja no plano familiar ou coletivo. Essa situação é portadora de um forte dilaceramento no interior dessas famílias. 
13. C ertamente, esse tema precisa ser situado sob a perspectiva da his tória da classe operária. A respeito, ver o novo prefácio de $\mathrm{N}$ oiriel (2002) à reedição deseu livro, já um clássico.

14. Encontramos-nos na mesma posição de N oiriel (2002), historia dor, quando evoca 0 momento em quecome çou sua pesquisa sobre Longwy, em 1979: “N o curso da luta de [Longwy], de 1979-1980, espantei-me com a amplitude do sentimento de incompreensão que osoperáriosem greveentão exprimiam. 0 discurso dos porta-vozes exteriores (sejam os governantes, dirigentes sindicais 'recentrados', jornalistas, sociólogosou outros) ilustrava suaignorância sobreas realidadessociaisehistóricas locais. D isso tirei aconclusão dequea melhor ajuda que eu poderia oferecer aos dominados consistianão em falar em seu lugar, tampouco afirmar peremptoriamente o que seria necessário fazer para resolver os 'seus' problemas. M ais modestamente, tratavase de meempenhar em expor a lógica de suas práticassociaisparaten-
M as qual herança operária? Sobretudo, assim nos parece, uma herança política. Por muito tempo, era própria dos operários a possibilidade de transmitir essa herança. Seria mesmo possível dizer que o "orgulho operário" procedia, em grande parte, dessa herança política. É claro, não se trata de dizer que esse orgulho desapareceu inteiramente. D ele ainda sobraram bel os vestígios em certos ramos profissionais (o que resta dos operários gráficos, dos ferroviários, dos operários altamente qualificados...), da mesma maneira como existem formas de solidariedade de chão de fábrica ou de seção. Poderíamostambém nos perguntar se não subsiste uma herança propriamenteoperária, institucional e política - uma herança objetivada - que pode ser utilizada, reativada, como podemos ver, agora, com a criação recente de seções sindicais em al gumas das novas pequenas ou médias empresas de subcontratação implantadas na região de $M$ ontbéliard.

Com essa questão daherança operária, o livro também trata da questão da autonomia simbólica do grupo operário. É aí que se encontra a questão do papel dosoperários profissionais (OP) na unificação do grupo operário ena valorização de certo tipo de experiência operária ${ }^{13}$. O s O P tinham, com ou sem razão, um fortesentimento do seu valor, em função desua própria profissão (uma formação propriamente operária, o certificado de qualificação, 0 virtuosismo manual, osestágios, a agilidade, o gosto ou o dom da bricolagem, o trabal ho das "mãos" etc.), e, deoutro lado, por força dafépor elesassumida nosvalores do socialismo.

\section{As transformações do trabalho operário: o que o campo faz "ver"}

Ao realizar nossa pesquisa, pudemos constatar, de partida e logo no seu início, uma imensa defasagem entre, de um lado, o que observávamos no campo - a intensificação do trabal ho, essa espécie de guerra social no interior das fábricas em nome da exigência de ganhos de tempo e de produtividade, a violência cotidianamente sentida pelos operários etc. - e, de outro, a representação dominante então corrente sobre a realidade operária - a conversão ao neo-management, a robotização e as novas tecnologias que pareciam fazer desaparecer, por milagretecnológico, a vel ha eincômoda questão operária ${ }^{14}$. N ão podíamos deixar de nos espantar com a imensa defasagem entreo queentão diziam os porta-vozes do mundo operário (sindical istas dos escalões mais elevados, os delegados permanentes etc.) e o quea "base" vivia, sua dificuldade cada vez maior de dizer o que havia a ser dito e, sobretudo, a dificuldade de ser ouvida, inclusive por aqueles que poderiam ser 
tomados como seus defensores naturais ("históricos"). D e fato, o mundo operário, desde o início dos anos de 1960, sempre se sustentou em dois pilares: aCGT (Confederação G eral do Trabalho) eaCFDT (Confederação Francesa D emocrática do Trabalho). A CFDT representava todo um lado do mundo rural, que havia, com freqüência, passado pela JO C (Juventude $O$ perária Cristã). $\mathrm{N}$ a medida em que a CFDT começou a se afastar em direção a outras paragens, o mundo operário terminou por perder uma de suas forças de sustentação. E isso desestabilizou profundamente o sindicalismo operário que se alimentava dessa rivalidade, mas também da emulação entreaCGT eCFDT.

M as é preciso também dizer - e enfatizar - que essas questões só puderam e só poderiam ser apreendidas com base numa pesquisa empírica, sobretudo delonga duração, com presença prolongada no meio social pesquisado. A tomar como ponto de partida as questões abstratas tais como foram "trabalhadas" pela sociologia das classes sociais ${ }^{15}$ (em particular, na França, a sociologia da "classe operária"), preferimos nos lançar, desde o início, em uma análise do material do campo. Procuramos encontrar o ponto de vista da experiência operária, as visões de mundo (e também as práticas), fazendo ouvir, o mais possível, certa palavra operária.

N a nova pai sagem ideológica dos anos de 1980, muitos foram os sociólogos ou economistas do trabal ho que tomaram por tema a modernização das empresas, mais precisamente a informatização da produção, as novas formas de organização do trabalho e de gestão da produção (fluxo-contínuo, just-in-time, flexibilidade e exigências de qualidade) difundidas nas empresas francesas nos últimos quinze anos. Por mais interessantes que se apresentem, essas análi ses são, no entanto, caracterizadas por um economicismo implícito e, com muita freqüencia, pela ausência de uma verdadeira perspectiva histórica (notadamente do ponto de vista da história dos grupos profissionais e sociais). Q uisemos estudar a forma como as transformações da organização do trabalho foram vividas, no correr dos anos, pelo "grupo" dos operários no próprio chão de fábrica, sem omitir, no entanto, os diversos pontos de vista sobrenosso objeto. Por meio de entrevistas aprofundadas, procuramos situar no centro de nosso dispositivo de pesquisa a restitui ção dos diferentes pontos de vista dos assalariados, em particular dos operários das seções de carroceria da fábrica de Sochaux. A reflexão sobre o trabal ho operário não pode ser isolada das condições concretas nas quais se efetua a cooperação operária: o trabal ho operário supõeformas de cooperação, a construção de relações coletivas, de onde a val orização da auto-ajuda tar explicála aosquenão acomprendem porque não a vivenciam; o que supõe uma proximidade geográfica e social com o universo tomado como objeto deestudo".

15. Em boamedida, essas questões, tais como formuladas, pareciam conter o risco denosfechar em um debatepré construído, em que as respostasjáestão previamentedadas. 0 quenão quer dizer, longe disso, que sejam desprovidas desentido. M asconside ramosque deveriam ser retomadas com baseem um material empírico. 
16.É possível, aqui, re tomar a análisesintética proposta por Pudal (2001, p. 517): "Sendo uma relação com a matéria, o trabalho ope rário supõe também uma relação coletiva, uma eficaz ciência da cooperação e do grupo. D aí esseculto da solidariedade, da auto-ajuda, da camaradagem, base comum de sustentação do militantismo operá rio edenumerosas outras práticas de classe. Jogo, festa, atividades várias, linguagem: a linguagem operária secaracteriza pela riqueza de léxicos da profissão e também por um uso extensivo defigurasemetáforas relativas ao corpo, quasesem recorrerà eufemização queéuma forma de se colocar a distância. Exprimese depreferência por meio decertosgêneros, como a piada ou a gozação, bem como mediantere pertórios anedóticos que tematizam a vida declassee dela extraem lições de forma menos rígida que os ditadose provérbios.

17. Por exemplo, o livro Retour... serviu de "guia" para o filme de Patrick Jan, “O uvrier, c'est pas laclasse" ( 0 perário, não e da solidariedade $\mathrm{e}^{16}$. M esmo que essas "realidades" tenham sido deturpadas (pela gestão dita "participativa"), não deixaram deser menos incontornáveis. Tratamos, portanto, de lidar com os diferentes temas desenvolvidos pelos pesquisadores nos anos de 1990, porém sob outras perspectivas eocupando lugares distintos no universo político. A pesquisa monográfica permitia abordar sucessi vamente objetos muito diferentes, dando, assim, uma visão caleidoscópica do mundo operário local. Por outro lado, tratávamos de seguir as coisas no tempo: apenas dessa maneira é possível apreender os diferentes ritmos e as diversas temporalidades sociais. É a combinação desses dois procedimentos de pesquisa que permite dar espessura - temporal e "humana" - ao material pesquisado. Eis o que também permite refletir sobre aquilo que poderíamos chamar, em um primeiro momento, de "defasagem" e, em seguida, indagar a respeito dos gruposque permitem que al go como um "ajustamento" ou equilíbrio possa se produzir.

Astransformações do mundo operário no âmbito

de um capitalismo selvagem renovado

A partir de 2001, a situação de desemprego em massa e de precariedade apenas se agravou. A desmoralização do grupo operário ficou ainda mais acentuada. E isso se manifestou por inteiro no primeiro turno das eleições presidenciais deabril de 2002: mais marcante do queo voto operário em Le Pen, foi o enorme crescimento do abstencionismo. A única, e notável, inversão de ten dência foi o fato de que os operários passaram novamente para o centro das atenções públicas, ganharam atualidade, em função do recente fechamento selvagem de fábricas e das demissões em massa que então se seguiram. Filmes (ficção ou documentários ${ }^{17}$ ) elivros sobrea condição ope rária são cada vez mais freqüentes. Talvez essa retomada de interesse seja parecida com a que desperta a "beleza do morto". D e toda forma, valeinsistir em al guns pontos das tendências recentes.

Além do medo do desemprego e da precariedade, verdadeira espada de D âmocles sobre a cabeça dos assalariados menos escolarizados, nesses últimos anos vem se acentuando a agressão social sobre os operários: demissões "econômicas", aumento dos acidentes de trabalho, disparada das doenças profissionais derivadas da aceleração desenfreada das cadências do trabal ho (os médicos do trabal ho têm dado, sem sucesso, o sinal de alarme sobre esse problema de saúde pública), competição institucionalizada entre assalariados, novas formas de dominação no trabalho, culpabilização dos assalaria- 
dos, pressão moral etc. Entre as empresas de equipamentos automobilísticos, tipo-ideal dos novos dispositivos produtivos cel ebrados pela imprensa gerencial, essas situações se repetem de forma evidente e o quadro das condições de trabal ho é extremamente sombrio. Q uanto às pequenas e médias empresas, o seu desenvolvimento vem trazen do um verdadeiro florescimento de novas formas de sweat shop ${ }^{18}$ isoladas em zonas rurais desertas ou em novas zonas industriais afastadas da cidadee de suas redes de sociabilidade, interditadas à visão externa.

D esde 1999, os traços do capitalismo acionário, ou melhor, de um capitalismo selvagem renovado (os "patrões delinqüentes" - licenciamentos selvagens, sem plano social e escassa consideração pelos direitos do trabaIho, desprezo pelos sindicatos, aniquilamento dos assalariados mais vulne ráveis, caça aos doentes e licenciados, aumento das doenças profissionais) suscitam a interrogação: nesses anos mais recentes, haveria o retorno de uma forma de experiência comum, um sentimento partilhado eintenso de despossessão? Q uestão pertinente não apenas aos operários pouco ou nada qualificados, mas também a muitos dos empregado(a)s e frações qualificadas do grupo operário, antes mais próximas das classes médias. Como diz D anièle Linhart,

[...] o sentimento deexploração, quesemprefoi abaseda identidadeoperária, persiste; háum profundo sentimento deinjustiça, porém vivido como sentimento privado, sem conseguir ganhar forma em termos coletivos. No entanto, trata-sededestinos coletivos. Paratodos, a centralidadedo emprego aparecedeformadramática após uma demissão: além da perda do emprego, o selo da obsol escência que os atinge ea desqualificação profissional, social epessoal. Percebem muito bem o sentido desse "mundo moderno" ao qual são remetidos: o mundo da adaptabilidade, da competitividade, da assim chamada iniciativa individual, em que cada trabal hador é constrangido a fixar ele mesmo os objetivos e obter de si o melhor rendimento possível. $\mathrm{N}$ a realidade, esse suposto mundo moderno significa a desqual ificação de populações inteiras (Linhart e Pialoux, 2004).

Para além dessas evoluções negativas, é preciso também ter em mente 0 quedizem muitos dosoperários entre 40 e 50 anos (os “antigos" nasfábricas), a saber: o que eles chamam de "antiga moral operária" foi de al gum modo corrompida pelasnovasformas degestão nas empresas. Esseéum ponto que nos parece essencial, muito freqüentemente despercebido nas análi ises sobre o mundo operário, apenas porque muitos jornalistas esociólogos desistiram éa classe), 2002. Rodado em Sochauxno momento de uma retomadaeconômica, em 2001, constitui um precioso documento para compreender a nova paisagem industrial daregião, o pleno emprego precário eas relações entreas gerações operárias.

18. D esignação parafábricas ou oficinas que mantinham, na Revolução Industrial, um ritmo extremamenteintenso, fazendo o operário ou operária trabalhar muitas horas ao longo de umajornada, sem descanso eganhando muito pouco. Literalmente, a expressão poderiaser traduzida como "suadouros". 
19. Parauma descrição parcial dessesuniversos, ver Pialoux e Beaud (2003).

20. Em seu Carnetsd'un interimaire, $D$ aniel M artinez (2003) ofere ce um apaixonantetestemunho, escrito em primeira pessoa por um trabalhador temporário com pouco mais de 40 anos, da região deBordeaux. de verificar o que se passa nesses locais de trabal ho subtraídos dos olhares exteriore ${ }^{19}$ (cineastas documentaristas vêm tentando, por vezes, ocupar 0 lugar dos sociólogos para forçar a entrada nesse universo). M as ainda não se avaliou suficientementeo medo, a multiplicação deformas de pressão, anecessidade de se desrecal car sobre os outros... Para compreender o caráter de protesto desesperado que muitas vezes assume, nos meios populares, o voto naFrenteN acional, épreciso considerar essa degradação multiformedas condições de trabal ho, a forma máxima da insegurança da qual tanto sefala.

N osúltimos vinteanos, o que desapareceu de todo foi a figura do "trabaIhador" - orgulhoso de seu trabal ho edesua contribuição à produção - ou a do operário, apoiado e sustentado pela "classe", portadora de história e de esperanças políticas. 0 utra imagem foi construída, a do "assalariado da precariedade" (Paugam), do operador, do operário mal eável eusado conformeas conveniências decada momento, reduzido à sua condição deoperário intercambiável, sem consciência de si. É possível ver, no voto do 21 de abril de 2002, uma revolta da Françalaboriosa, a quetrabal ha duro cada vez mais para ganhar cada vez menos (o salário mínimo como horizonte insuperável do salário operário?), essa França quefoi formada na antiga moral do trabal ho e cujos rudimentos demoral popular bastavam para ditar umalinha de conduta, uma "conduta de vida", como diria M ax Weber (esses valores moraisconsiderados simples: trabalho, honestidade, respeito pelos outros, posse de algunsbens). É preciso insistir sobrea incapacidadedos responsáveis políticos em medir o quea precariedadesignifica concretamenteparaasfamílias populares ${ }^{20}$ : encolhimento do horizonte temporal, redução das possibilidades de prever ecalcular o futuro (essa previsibilidadee cal culabilidadeforam historicamente comportamentos característicos dasfrações operárias quesedestacaram do "subproletariado"), medo einqui etação em relação à saúde, exposição crescenteaos riscos detrabalho.

\section{Um mundo operário desarmado}

Lembrete histórico: na França, a politização operária passou fundamentalmente pela mediação dos militantes. Agora, esses militantes são cada vez menos numerosos. A espécie de guerra social desenvolvida nesses últimos vinte anos para reduzir o movimento operário trouxe seus frutos, em grande escala. A batal ha travada nas empresas para atingir, desmoralizar e demitir os "delegados" - esses empecilhos à tranqüila exploração da mão-de-obra foi muito bem-sucedida, atémesmo além das esperanças patronais (a ponto 
de que, hoje, se lamenta a ausência de representantes sindicais). N o entanto, nos salões da República, isso é al go que ninguém quer reconhecer, ape sar dos gritos de alarme lançados pelos inspetores de trabal ho. 0 s pedidos de socorro dos sindicalistas de empresa mal foram ouvidos. Então, por que tamanha indiferença? Por certo, há razões conjunturais. Porém, mais fundamentalmente, trata-se de uma enorme incompreensão do que representou essa figura social do militante operário e um não menor desconhecimento do papel e da função social dos "delegados" nas fábricas. É possível ver nisso uma forma de desprezo social em relação ao delegado operário. E seria também possível dizer que esse desprezo tem uma história intimamente ligada à do PCF, a seu êxito histórico: assegurar uma representação operária encarnada nos eleitos do povo ${ }^{21}$, impor aos "dominantes" a presença operária na cena pública. Ao destruir os antigos bastiões industriais e um amplo segmento do grupo dos operários profissionais, a crise pulverizou a representação operária em grande partegarantida pelo PCF e pelaCG T, mas também pela CFDT e pelas diferentes correntes do catolicismo de esquerda. No curso desses anos de modernização conservadora, essa quase revanche de classe se expressou no plano simbólico mediante um empenho sistemático de desval orização dos representantes operários (para tomar apenas um exemplo, o modo como os sindicalistas foram caricaturados no Les guignols de l'info'22 nos anos de 1990).

É preciso dizer com todasas letras: o enfraquecimento do mundo operário tem causas quenão se reduzem apenasà dimensão econômica, às causas "objetivas", como se diz. Explica-setambém por transformaçõesimportantesna imagem construída de si mesmo, que tem estreita relação com transformações do campo intelectual. Paradizêlo demodo brutal: o movimento operário foi também desarmado por análises semi-esclareci das epela cegueira não apenas dos intelectuais mediáticos, mas também de pesquisadores sorvidos pela "modernidade". N esse quadro, não se pode deixar de considerar o que ocorreu no seio do PS (Partido Socialista) e da CFDT. Esta última operou uma guinada deorientação motivada em grandemedida por uma falsa profecia - o desaparecimento inelutável dosoperários- epor uma visão olímpica do movimento operário, com basena rejeição detudo o quepoderialembrar as atitudes "classistas" da CG T. D efato, a doxa de ampla circulação nas altas esferas da esquerda intelectual proclamava que os operáriossão arcaicos, têm uma mentalidadeultrapassada, não conseguem ou não querem seadaptar aos novos tempos, e seriam simplesmente marginalizados na medida em que a novaterceirarevolução industrial anunciavaa sua rápida extinção. N a relação
21. Sobre essa questão, ver o livro fundamental de Bernard Pudal (1989).

22. Emissão satírica de marionetesdifundidana cadeiatelevisivafrancesa, fazendo a caricatura do noticiário dosprincipais telejornais. 
queo PS eaCFTD mantiveram com o movimento operário, pesou demodo considerável certa obsessão anticomunista, que chegou à exasperação entre algunsintelectuais orgânicos da CFDT. N o seu conjunto, tudo isso teve um papel importanteno modo como os operários se viram desarmadosintelectualmente, "empurrados para o recuo" justo no momento deencetar combates decisivos. Trata-se, aqui, deuma desqualificação bem francesa do mundo operário, que se realiza por meio da tentativa de liquidação das "vantagens sociais", materiais e simbólicas, das lutas operárias de um período de PCF forte, deumaCGT potente, deumaCFD T operária. M al ou bem, o sistema derepresentação dosanos de 1950 e1960, quesepodequalificar de "stalinista", assegurou à "base" operária uma notável qualidade moral e uma forte autonomia simbólica, efoi capaz de produzir militantes deestatura, que "se impunham". M astudo isso foi esquecido, éagora visto como peças demuseu daH istória.

\section{0 descolamento das classes populares no espaço social}

A desvalorização do grupo operário deve ser analisada tanto objetivamente, por intermédio de indicadores econômicos (salários, renda, bens, trajetória dosfilhos), como relacionalmente, isto é, por referência à situação dos outros grupos socioprofissionais que também compõem o meio popular. É preciso levar em conta a constelação dos outros grupos sociais com os quais os operários coexistem e com os quais comparam suas condições de existência, notadamente os pequenos funcionários, os operários das empresas estatais, os funcionários municipais etc. N os últimos vinte anos, produziu-se um duplo movimento: primeiro, o "descolamento" das classes populares no espaço social; segundo, uma clivagem cada vez mais acentuada entre, de um lado, sua fração numericamente mais importante, ligada ao setor privado (os operários fabris, os empregados de serviço), sempre mais pressionada e submetida ao "chicote" do mercado e às arbitrariedades dos "chefes" nos locais de trabal ho, e, de outro, a fração do setor protegido no mercado de trabalho, que mal ou bem se beneficia de uma segurança de emprego, queéfortemente sindicalizada ea qual consegue defender-se (ferroviários, empregados dos correios, operários das empresas estatais, pequenos funcionários). D isso resulta uma rivalidade crescente no espaço social, perceptível nas conversas e nos comentários crivados de pesada ironia críti$\mathrm{ca}$, que circulam entre os primeiros, muito freqüentemente tendo em mira esses que são considerados os "privilegiados" nos serviços públicos. Q uer 
nos parecer que houve uma interpretação exagerada da greve dos ferroviários de 1995. Por certo, ela foi importante, conseguiu vitórias e impôs a suspensão temporária dos projetos da direita. Porém, não chegou a se difundir no setor privado, ebeneficiou pouco ou quasenada os demais operários. Pode ser que tenha existido um sentimento de greve por procuração, mas de fato não houve greves no setor privado. Por outro lado, terminou por colocar em evidência a distância crescente das condições entre os dois grupos e forneceu uma medida da enorme vantagem da garantia de emprego. O s operários das empresas públicas escaparam da lógica da concorrência que atingiu fortemente os trabal hadores do setor privado. É como se a mecânica de difusão dos benefícios sociais, do ganho das lutas que antes unificava e homogeneizava relativamente as classes populares (cf. o caso sempre evocado dos operários da Renault), tenha sido sustada nas duas últimas décadas.

Por conseguinte, as lógicas de identificação, apoiadas em uma crença no progresso, que por muito tempo contribuíram para a unificação das classes populares, não podem mais se desenvolver como antes. Elas estão travadas, em pane, como 0 antigo sistema de promoção operária. $\mathrm{N}$ a configuração social do pós-guerra, existia um sistema de promoção que, hoje, está inteiramente rompido. A reestruturação das empresas permitiu contornar as antigas fortal ezas operárias, levou à atomização da mão-de-obra nas pequenas e médias empresas, quase sempre subcontratadas, e terminou por fazer surgir um mundo marcado pela clivagem entre, de um lado, os técnicose, deoutro, os operadores sob pressão constante e em permanenteconcorrência nos postos de trabalho. $\mathrm{H}$ oje, não existe mais uma elite operária. $\mathrm{Os}$ novos operários qualificados têm um perfil técnico e suas aspirações voltamse sobretudo para as classes médias, tentando se diferenciar de tudo o que possa evocar ou lembrar a "condição" operária (recusam a palavra "operário" para se autodefinir). No início da década de 1990, os operários com diploma técnico ainda conseguiam se identificar com os operários profissionais (eram "franceses", tinham estudado, eram relativamente orgulhosos de seus diplomase, por vezes, assumiram combates comuns, como no caso da greve deBelfort-Alstom, de 1993). M as as coisas evoluíram depressa: esses diplomas foram desvalorizados e os liceus profissionais são cada vez mais freqüentados pel os jovens mais desqual ificados social mente, em grande parte filhos de famílias imigradas. Por outro lado, o sentimento de descolamento e de desclassificação é tão forte que essas frações inferiores do grupo operário se sentem enganadas pelo Estado Providência e ameaçadas pela sua proximi- 
23. Forma abreviada e correnteparadesignaros beneficiáriosdeum amplo programa de renda mínimadeinserção alocado aoschamados"novospobres", implantado na França no final dos anosde1980 (N .T.).

24. Partido deextremadireita fundado por Jean-M arie Le Pen em 1972 eque passa a ganhar forçapolíticaedetoral no correr dosanos de 1980 (N. T.).

25. Problema quesecoloca na medida mesma em que o acesso à propriedadeea urbanização periférica se difundem cada vez mais entre as famílias migradas que querem fugir dos conjuntoshabitacionais. $0 \mathrm{~s}$ geógrafos, por ocasião das eleições deabril de 2002, verificaram um acentuado aumento do voto na FN nas zonas periféricas da "terceira coroa" parisiense (0 ise, EureeLoir). Seushabitantes avaliam, agora, 0 custo econômico esocial do acesso à propriedade e se dão conta de que nem por isso se viram livresdosproblemassociaisquequiseram evitar ao deixar a periferia. dade, objetiva, com os "excluídos" e os Rmistes²3. D aí também a preocupação em se diferenciar desses últimos, muitas vezes acusados de "falsos desempregados" ou "preguiçosos".

A recorrência do expressivo desempenho eleitoral da FN (Frente N acional ${ }^{24}$ nos últimos quinze anos serve de prova: um racismo duradouro se instala no mundo das classes populares francesas. Ele existe de formas diversas: desde aquele declarado e assumido, até aquele negado ou oculto. $M$ as é um racismo que muito dificilmente irá diminuir. D e um lado, no meio operário, éalimentado pelo sofrimento no trabal ho e pelo "medo" (do desemprego, da desclassificação, do futuro). D e outro, é um racismo maciçamente legitimado pelo desempenho eleitoral da FN, portanto aberto, declarado, às vezes ostensivo. É um racismo também al imentado pelosacontecimentos do 0 riente $M$ édio, cujas repercussões são imediatas na vida das periferias, mais ainda nos conjuntos habitacionais. É preciso interrogar-se pelas razões dessa queda parcial do tabu do racismo nos meios populares (por certo existe um racismo ideológico, que é bem diferente, praticado pela extrema-direita nacionalista, e do qual não tratamos aqui). São questões complexas, que merecem um exame etnográfico detalhado, mas que devem ser analisadas à luz de um duplo processo: primeiro, a "transferência da memória" e o impensado da questão colonial na sociedade francesa; segundo, as formas concretas do racismo antimagrebino e do contra-racismo que surgiu em reação nesses últimos vinte anos.

M erece igual atenção o voto da juventude popular na FN - no segundo turno das eleições de 2002, 21\% na faixa dos 18 aos 24 anos, 22\% entreos 25 e os 34 anos. Para compreender esse voto, é preciso levar em conta questões pertinentes à socialização escolar e resi dencial. Esses jovens que votaram na FN freqüentemente passaram pelas fileiras mais desval orizadas do sistema escolar e, nas escolas, se viram confrontados com os jovens dos conjuntos habitacionais eque têm, a seu favor, a força do número. Sentiram-seem minoria eforam, por vezes, roubadose agredidos. São os mesmosque, quando adultos - operários, precários ou desempregados - , se encontram em situação deconcorrência com eles; al guns podem tender a se vingar das humilhaçõessofridasna escola eno espaço público por um voto cada vez menos camuflado naFN . Por outro lado, parteda explicação também pode estar no fato de que esses jovens, ten do crescido nos loteamentos destinados à moradia própria, a partir decerto momento perceberam quea fuga dosconjuntos habitacionais e a "redenção" residencial pelo acesso à propriedade não significam uma total ruptura com os problemas das periferias ${ }^{25}$. 
Finalmente, é preciso voltar atrás e também levar em conta o que se passou, nessas duas últimas décadas, na escola ena relação entre os educadorese osoperários. D efato, criou-seuma enormedistância entre esses doisuniversos: parteconsiderável dos educadores ignora inteiramente a transformação do trabal ho nasfábricas, tem representações equivocadas sobrea vida operária, um número crescente del es pareceestar à distância da tarefa emancipatória antes assumida como sua missão eal guns chegam a desenvolver, nas escolas "difíceis", um discurso bastante reacionário (cf. o sensível deslizamento à direita do voto dos educadores no primeiro turno das eleições presidenciais). D eoutro lado, os operários entrevistados em nossas pesquisas tendem auma percepção cada vez maisnegativa dos educadores: são vistos como "pequenos burgueses" instalados em sua história e em seu conforto material, indiferentesà sortedosmais desfavorecidos, com uma irritantetendência a "dar lições demoral". É bem relevanteo queestá em jogo nessa relação entreeducadores e operários: a decepção em relação à escola e as desilusões com a chamada política de democratização do ensino terminaram por alimentar uma profunda desconfiança em relação aos ideais de esquerda, ao mesmo tempo em queoseducadoresnão seconsideram mais, "naturalmente", como "esclarecedores", intermediários culturais encarregados de transmitir uma cultura moral e política aos jovens das classes populares.

\section{Conclusão}

0 grupo operário éum grupo social com perdadevelocidade, cujosmembros, individual e coletivamente, têm a impressão de terem sido, ao mesmo tempo, as vítimas e os enganados da história recente. Vale dizer que muitos dos operários eleitores da FN se declaram, no entanto, de "esquerda". H á nisso justamente o peso dessa decepção e, para os mais engajados (alguns militantes), um sentimento muito intenso de "traição". É preciso, portanto, enfatizar o chão social no qual seenraíza o voto operário nos extremos: afunda desestabilização das antigas identidades operárias. 0 s acontecimentos da cena política nesses últimos vinteanos não são mais do quea tradução desse processo central que é a perda da sustentação da "classe" para os operários. Além delhesassegurar proteção social, ela possuía uma enormeforça deidentificação. Essas lógicas e esses modelos de identificação foram rompidos. Estamosassistindo aum embaralhamento completo das oposições queestruturavam o mundo operário, ea maisfortedelasera aquel a que separava objetivamenteosoperários qualificados dos não-qualificados. N a medida em que 
se desfazem as forças de identificação coletiva (os militantes de fábrica, as associações locais, os partidos) e que o grupo operário, disperso no espaço geográfico, se vê confrontado com o mundo das classes médias nas zonas residenciais, cada vez mais os operários tendem a se identificar socialmente por meio do consumo (a casa, o automóvel, as férias, as marcas deroupa etc.) esão, por isso mesmo, "trabal hados" pel o fantasma da desclassificação social. Tais processos dedesestruturação do grupo operário e, maisamplamente, das classes populares são fenômenos deenvergadura. N ão basta tomar consciência do problema a fim de amortecer seu impacto, muito menos a denúncia moral. Será preciso reduzir a distância ou refazer as pontes entre as frações progressistas da classe média e as classes populares, sobretudo pela redução dos diferenciais de salário entre os funcionários e os assalariados manuais, protegendo o mundo do trabal ho contra os efeitos de implosão das novas formas decapitalismo selvagem, bem como recuperando o poder emancipador da escola.

\section{Referências Bibliográficas}

Beaud, Stéphane. (2002), 80\% au bac. Et après?... Lesenfantsdela démocratisation scolaire. Paris, La D écouverte.

Beaud, Stéphane\& Pialoux, M ichel. (2003), Violencesurbaines, violence sociale. Paris, Fayard.

Lin haRT, D anièle\& Pialoux, M ichel. (2004), "D ialogueentreet M ichel Pialoux”. Regards, février, Paris.

M artinez, D aniel. (2003), Carnetsd'un intérimaire Paris, Agone.

N oIRIEL, Gérard. (2002), "Préface”. In: . Lesouvriersdansla sociétéfrançaise. Paris,

Points-Seuil.

PUdAL, Bernard. (1989). Prendreparti : pour unesociologiehistoriquedu PCF. Paris, FN SP. . (2001), Lesièdedescommunismes. Paris, Editions del'Atelier.

\section{Resumo}

Rebeliões urbanas e a desestruturação das classes populares (França, 2005)

Tomando como ponto de partida a rebelião urbana ocorrida na França em outubronovembro de 2005, os autores chamam a atenção para o que consideram novidade em relação às outras ocorridasna França nasúltimas décadas: a participação dejovens "ordinários", por vezes bem situados no sistema de ensino eintegrados no mercado de trabal ho, porém quase sempreem situações precárias einstáveis, sem chances deevoluir socialmente. Evidência primeira de uma profunda degradação das condições de trabal ho nosúltimos 
anos, osautorestecem um quadro social em quesearticulam desemprego, trabal ho precário e fechamento de horizontes de futuro, situações de fracasso escolar e agravamento da segregação urbana, junto com formas abertas de racismo que atingem diretamente os jovensfilhos de famíliasimigrantes, em boa partemoradores dos conjuntoshabitacionais. A questão proposta pelos autores é a necessidade de inscrever esses acontecimentos no quadro mais amplo da desestruturação das classes populares francesas, ou seja: a questão importante a ser compreendida éa condição operária “após a classe operária”. O sautores retomam discussões deseu livro Retour sur la condition ouvrière(1999), com o agravamento da condição operária nos anos mais recentes, da qual ossinais deracismo no meio operário são ao mesmo tempo sintoma e efeito.

Palavras-chave: Rebeliõesurbanasna França; D ecomposição da classeoperária; Ruptura de gerações; D egradação da condição operária; D essolidarização dasclasses populares.

\section{Abstract}

Urban revolts and the destructuring of the working class (France 2005)

Taking as astarting point the urban revoltsthat exploded in France in 0 ctober-N ovember 2005, the authors call attention to a new aspect distinguishing these events from other forms of civil protest in France during the last few decades: theinvolvement of 'ordinary' youths, often well placed within the educational system and integrated in thework market, but almost always in precarious and unstable situations, without chances to evolve socially. Providing primary evidence of a profound deterioration in working conditions over recent years, the authors describe a social setting that combines unemployment, precarious work and the closure of future prospects, failures in schooling and the worsening of urban segregation, al ongside open forms of racism that directly affect the young children of immigrant families, in large part residents of housing estates. The question proposed by theauthorsistheneed to locate these events within the broader setting of the destructuring of the French working class. The key question to be understood is the working condition "after the working class." The authors resume discussions found in their book Retour sur la condition ouvrière (1999), analyzing the worsening of working conditions in more recent years and noting that the signs of racism in the working class environment are both a symptom and an effect.

Keywords: U rban unrest in France; D ecomposition of the working class; R upture of generations; D egradation of working conditions; Loss of working class solidarity.
Texto recebido e aprovado em 10/4/2006.

Stéphane Beaud éprofessor de sociologia da Universidade de $\mathrm{N}$ antes. E-mail: beaud@elias .ens.fr.

M ichel Pialouxépesquisador do Centro deSociologia Européia, CNRS. E-mail: michel. pialoux@free.fr. 